\title{
Effect of milking frequency and feeding level before and after dry off on dairy cattle behavior and udder characteristics
}

\author{
C. B. Tucker, ${ }^{\star} \dagger^{1}$ S. J. Lacy-Hulbert, $\ddagger$ and J. R. Webster* \\ ${ }^{*}$ AgResearch Ltd., Hamilton, New Zealand, 3240 \\ †Department of Animal Science, University of California, Davis 95616 \\ ‡Dairy NZ, Hamilton, New Zealand, 3240
}

\section{ABSTRACT}

The effects of 2 common dry-off management procedures, feed restriction [8 vs. $16 \mathrm{~kg}$ of dry matter $(\mathrm{DM}) / \mathrm{d}]$ and reduced milking frequency (once, $1 \times$ vs. twice, $2 \times / d$ ), on the behavior and udder characteristics of dairy cattle were assessed in late lactation and the early dry period. Milking cows $1 \times$ instead of $2 \times$ in the week before dry off reduced milk yield (7.0 vs. $8.9 \pm$ $0.95 \mathrm{~kg} / \mathrm{d}$ for $1 \times$ and $2 \times$, respectively), but had little effect on behavior before or after cessation of milking. In comparison, feed restriction reduced milk yield (6.9 vs. $9.1 \pm 0.95 \mathrm{~kg} / \mathrm{d}$ for 8 and $16 \mathrm{~kg}$ of $\mathrm{DM} / \mathrm{d}$, respectively), udder firmness after dry off (7.3 vs. $8.0 \pm 0.24 \mathrm{~g}$ force for 8 and $16 \mathrm{~kg}$ of $\mathrm{DM} / \mathrm{d}$, respectively), milk leakage ( 2 d after dry off, $14 \%$ of cows offered $8 \mathrm{~kg}$ of DM/d were leaking milk compared with $42 \%$ cows offered $16 \mathrm{~kg}$ of $\mathrm{DM} / \mathrm{d}$ ), and the likelihood of Streptococcus uberis intramammary infection (nonclinical mastitis; 12.5 vs. $62.5 \%$ of groups with at least 1 cow with a new intramammary infection for 8 and $16 \mathrm{~kg}$ of $\mathrm{DM} / \mathrm{d}$, respectively). Despite these benefits, cows offered only $8 \mathrm{~kg}$ of DM/d spent less time eating (7.3 vs. $8.3 \pm 0.28$ $\mathrm{h} / \mathrm{d}$ for 8 and $16 \mathrm{~kg} \mathrm{DM} / \mathrm{d}$, respectively), more time lying $(8.8$ vs. $7.3 \pm 0.24 \mathrm{~h} / \mathrm{d})$, and vocalized more before dry off than cows offered $16 \mathrm{~kg}$ of DM/d (0.8 vs. $0.2 \pm$ 0.15 calls/min for 8 and $16 \mathrm{~kg}$ of $\mathrm{DM} / \mathrm{d}$, respectively). These behavioral changes indicate that this level of feed restriction may cause hunger. Information is needed about alternative dry-off procedures that maintain the health benefits and comfort associated with lower milk yield before dry off but prevent hunger, such as feeding low quality diets ad libitum.

Key words: behavior, dry off, milking frequency, udder firmness

Received November 25, 2008

Accepted March 9, 2009.

${ }^{1}$ Corresponding author: cbtucker@ucdavis.edu

\section{INTRODUCTION}

Both feed restriction and reduced milking frequency are used to lower milk yield around the time of dry off or cessation of milking (Bushe and Oliver, 1987). These management tools can be used in combination or alone, and feed restriction can be employed both before and after milk cessation. Little evidence exists about the popularity and use of various dry-off procedures, but lower milk yields result from both feed restriction (Agenäs et al., 2003) and reduced milking frequency (Davis et al., 1999). Feed restriction reduces milk yield, in part, via downregulation of the mammary glucose transport system, including reduced arterial blood flow and prolonged transit time of blood through the mammary gland (Farr et al., 2000; Shennan and Peaker, 2000). In the short term, milking cows less often reduces milk yield by alveolar distension (resulting in smaller cells) and a reduction in blood flow. Reduced milking frequency caused cell death, which results in reduced milk yield (Davis et al., 1999). Lower milk yields at dry off considerably reduced the risk of IMI during the early dry period and at calving (Dingwell et al., 2004; Rajala-Schultz et al., 2005; Odensten et al., 2007a).

Despite the benefits of reducing milk yield before dry off, there are concerns about the effects of both feed restriction and reduced milking frequency on dairy cattle welfare (Valizaheh et al., 2008). Restriction of nutrients in late lactation and during dry off represent a metabolic challenge to cattle, resulting in greater blood NEFA and cortisol levels (Odensten et al., 2007a,b). Cows exhibit behavioral signs of distress, such as vocalization, around the time of dry off (Valizaheh et al., 2008). Although physiological changes associated with feed restriction may be important to end lactation, it would be undesirable for cows to experience hunger during this process.

In addition to concerns about feed restriction, there are concerns that cows milked only once daily $(\mathbf{1} \times)$, or not at all, experienced discomfort associated with udder distension and inflammatory response (Davis et al., 1998). There is limited evidence that missed milkings or reduced milking frequency may cause discomfort. 
Cows that miss a milking because of mechanical failure spend less time lying down in the hour following the omitted milking compared with animals without a missed milking (Stefanowska et al., 2000). In addition, cows milked twice daily $(\mathbf{2} \times)$ had shorter lying bouts compared with animals milked thrice daily, and this difference may be due to discomfort associated with udder distension (Österman and Redbo, 2001). These results were not replicated in pasture-based systems when cows underwent the transition from $2 \times$ to $1 \times$ in mid-lactation (Tucker et al., 2007). An acute dry-off management strategy may result in more discomfort than reduced milking frequency, because of the accumulation of milk over several days.

The objective was to assess the effects of 2 common dry-off management procedures, feed restriction and reduced milking frequency, on the behavior, udder characteristics, and health of dairy cattle in late lactation and the early dry period. If reduced milking frequency and cessation of milking at dry off caused discomfort, we predicted that cows would spend less time lying down, be more likely to lie in positions that reduced pressure on the udder, have firmer udders, and be more likely to leak milk compared with cows milked $2 \times$ and before dry off. In addition, we predicted that if feed-restricted cows were hungry they would vocalize more and that the reduction of time spent eating would not be proportional to the difference in feed intake; in other words, that cows would continue to graze pasture in search of food. We predicted that both feed restriction and reduced milking frequency would reduce milk yield before dry off and IMI after dry off.

\section{MATERIALS AND METHODS}

\section{Cows and Treatments}

All values in this section are presented as means \pm SD. Sixty-four Holstein-Friesian cows were selected from the AgResearch research herd at Ruakura (Hamilton, New Zealand) during April and May 2006 (ambient temperature: $14.5 \pm 3.6^{\circ} \mathrm{C}$ ). This herd calved in spring (July to September 2005); thus, all cows were at a similar stage in lactation $(240 \pm 23$ DIM). Cows with a recent (within $1 \mathrm{mo}$ ) history of clinical mastitis were excluded from the experiment, as were cows producing $<4.5 \mathrm{~kg}$ of milk/d. At the start, cows had a BW of 476 $\pm 53 \mathrm{~kg}$, a BCS of $4.3 \pm 0.4$ (on a 1 to 10 scale; Roche et al., 2004), produced $9.6 \pm 2.9 \mathrm{~kg}$ of milk/d, and had a parity of $4.6 \pm 2.0$ lactations. The effects of feeding level (estimated DMI of 16 or $8 \mathrm{~kg}$ of DM/d) and milking frequency $(1 \times$ or $2 \times)$ were examined for their influence on responses to the dry-off process. Treatments were assigned to 16 groups of 4 cows with the group serving as the experimental unit. Cows were assigned to groups randomly, while balancing for milk production. Groups were formed $3 \mathrm{~d}$ before treatments were imposed. Groups were assigned to 1 of 4 treatments in a $2 \times 2$ arrangement randomly $(16 \mathrm{~kg}$ of $\mathrm{DM} / \mathrm{d}, 2 \times ; 16$ $\mathrm{kg}$ of DM/d, $1 \times ; 8 \mathrm{~kg}$ of DM/d, $2 \times ; 8 \mathrm{~kg}$ of DM/d, $1 \times$ ) for 14 consecutive 24 -h periods (the experiment ended on the morning of $\mathrm{d} 15)$. Cows were milked for the last time on $\mathrm{d} 7$ of the experiment (last milking was an a.m. milking for $1 \times$ cows, and a p.m. milking for $2 \times$ cows), thus $\mathrm{d} 8$ was the first day of the dry period.

Cows grazed predominantly perennial ryegrass-white clover pasture, with a pregrazing pasture cover of 2,720 $\pm 570 \mathrm{~kg}$ of $\mathrm{DM} / \mathrm{ha}$ and were supplemented with pasture silage. Both fresh pasture and pasture silage were provided every $24 \mathrm{~h}$ in the morning. Feeding treatments were created by manipulating both the amount of pasture and the silage provided. Cows on the $16 \mathrm{~kg}$ of $\mathrm{DM} / \mathrm{d}$ treatment were offered a pasture break that provided approximately $8 \mathrm{~kg}$ of DM/d per cow, and were supplemented with $8 \mathrm{~kg} \mathrm{DM} /$ cow of silage. Cows on the $8 \mathrm{~kg}$ of DM/d treatment were offered a pasture break that was half the size of the $16 \mathrm{~kg}$ of $\mathrm{DM} / \mathrm{d}$ treatment (approximately $4 \mathrm{~kg}$ of DM/d), supplemented with $4 \mathrm{~kg}$ of $\mathrm{DM} /$ cow of silage. Postgrazing pasture residuals of $1,800 \mathrm{~kg}$ of DM/ha were targeted. All cows were milked in the morning, between 0530 and $0720 \mathrm{~h}$, and the afternoon milking $(2 \times$ cows only) took place from approximately 1430 to $1530 \mathrm{~h}$. Feeding treatments (16 or $8 \mathrm{~kg}$ of $\mathrm{DM} / \mathrm{d}$ ) continued after dry off, and behavioral and udder responses were measured until the morning of d 15. All cows had access to fresh water in their grazing area. The study was conducted with the approval of the Ruakura Animal Ethics Committee (AgResearch, Hamilton, New Zealand).

\section{Milk Yield, Milk Leakage, and Udder Firmness}

Individual cow milk yields were recorded electronically (MM25 fast flow meters, DeLaval, Tumba, Sweden) on a per milking basis, and daily milk yields were calculated from $\mathrm{d}-2$ to 7 . Upon entry into the milking parlor, at the a.m. milking on $\mathrm{d} 1,3,5$, and 7 and upon entry into a separate restraint area (approximately 1 $\mathrm{km}$ away from parlor) after dry off, on d 8, 9, 10, 11 and 14, milk leaking from teats was recorded. After recording information about milk leakage, udder firmness was measured by pressing a steel rod (10 $\mathrm{mm}$ in diameter) against a marked spot in the middle of both rear quarters of the mammary gland (Tucker et al., 2007). The steel rod was attached to a spring and provided an estimate of the grams of force required to bring $5 \mathrm{~cm}$ of the steel rod flush with the surrounding Plexiglas plate (radius $5 \mathrm{~cm}$ ). This device measured a range of force 
Table 1. Definitions of behaviors used to evaluate the effects of milking once or twice daily on cows offered a high (16 kg of DM/d) or low (8 $\mathrm{kg}$ of $\mathrm{DM} / \mathrm{d}$ ) level of feed during the dry-off period

\begin{tabular}{ll}
\hline Behavior & Definition \\
\hline Eating & Feed was ingested or head moved side to side, with mouth/nose in contact with grass or silage \\
Standing, not eating & Upright, but not eating \\
Lying & Flank was in contact with ground \\
Positions while lying: & Weight placed on side of the body \\
Lying laterally & Underside leg bent at knee and hoof pointed back toward body \\
Underside front leg, bent & Exposed leg bent at knee and hoof pointed back toward body \\
Exposed front leg, bent & Exposed hind leg bent at less than 90 angle \\
Exposed hind leg, bent & When leg was tucked, there was no visible gap between the metacarpus and fetlock joint \\
Exposed front leg, touching & Exposed hind leg (metatarsus) touched body or udder \\
Exposed hind leg, touching &
\end{tabular}

from 0 to $13 \mathrm{~g}$. An average value of the left and right readings was used in the statistical analysis.

\section{IMI}

Foremilk samples were collected aseptically from all quarters for bacteriological analysis on 3 occasions: on d 0 and 6 (before dry off) and on d 15 (after dry off). Samples were collected and examined microbiologically according to guidelines of the National Mastitis Council (NMC, 1999). Teat ends were first scrubbed with cotton wool swabs soaked in $70 \%$ alcohol and allowed to dry. The first 2 to 3 squirts of milk were discarded and then approximately 10 to $20 \mathrm{~mL}$ was drawn into a sterile container. For each quarter, a subsample of $10 \mu \mathrm{L}$ of milk was streaked onto 1 quadrant of a $0.1 \%$ esculin, $5 \%$ sheep's blood agar plate (Fort Richard, Auckland, New Zealand) and incubated for $48 \mathrm{~h}$ at $37^{\circ} \mathrm{C}$. Presumptive identification of isolates was made based on colony morphology, Gram stain, catalase test, hemolysis pattern, tube coagulase test, esculin reaction, inulin fermentation, sodium hippurate reaction, and Christie, Atkins, Munch-Petersen (CAMP) test. Intramammary infection was diagnosed by a monoculture of $>200 \mathrm{cfu} /$ $\mathrm{mL}$ in a single quarter sample. Intramammary infections were divided into 2 categories: clinical mastitis (CM) and nonclinical mastitis (non-CM) based on visible changes in the gland secretion.

\section{Mastitis Management}

Unless stated otherwise, all quarters remained untreated with antibiotics until after the final bacteriological sampling (d 15), at which point all quarters were administered a tube of dry-cow antibiotic treatment (DCT; $600 \mathrm{mg}$ of cloxacillin; Orbenin Enduro, Pfizer Animal Health, Auckland, New Zealand). There were 2 exceptions. First, those quarters from which a major mastitis pathogen (Staphylococcus aureus, Streptococcus dysgalactiae, or Streptococcus uberis) was isolated on d 0 received an intramammary tube of DCT after the last milking. Second, quarters that were detected with signs of CM after dry off, such as heat, pain, or swelling of the udder, and clots in the secretion, were sampled for bacteriology, and then infused with a tube of lactating cow intramammary antibiotic (200 $\mathrm{mg}$ of cloxacillin; Orbenin LA, Pfizer Animal Health) each day for $4 \mathrm{~d}$. At the end of this course, a tube of DCT was administered. Cows with multiple quarters affected were treated i.m. over $4 \mathrm{~d}$ with 4 injections of $5 \mathrm{~g}$ of tylosin base (Tylan 200; Elanco Animal Health, Auckland, New Zealand). All quarters were sanitized after every milking by spraying with an iodophor postmilking teat sanitizer (KontACT, DeLaval).

\section{Time Budgets and Lying Behavior}

The behavior of cows at pasture was recorded for eight 24-h periods (before dry off: d 1, 3, 5, 7, and after dry off: $\mathrm{d} 8,9,10,14)$. One observer recorded the behavior of all cows in 4 groups ( 1 group from each treatment) with instantaneous scan sampling every $10 \mathrm{~min}$. Observers worked in 8-h shifts. For each cow, the time spent eating, standing without eating, and lying was recorded (Table 1 ). In addition, when the cows were lying, leg positions and whether the cows were lying with their weight on their side were recorded. Individual cows were identified with collars and unique symbols on their side painted with animal markers (Tell-Tail paint, FIL NZ Ltd., Mount Maunganui, New Zealand). Headlamps (Tactikla-plus, Petzl, Crolles, France) were used during night observations and a hand-held flashlight was used if additional light was required. Multiple observers were used to collect the behavioral information at pasture. Interobserver reliability, as measured by kappa coefficient of reliability, was between 0.91 and 0.99 for all behaviors except when assessing whether the exposed hind leg was bent (kappa $=0.84$ for this behavior).

Gemini Tiny-Tag data loggers (Gemini Dataloggers Ltd., Chichester, UK) were used to measure the number and duration of lying bouts for 1 (d 1 to 5 for 12 groups) or 2 cows in each group (d 1 to 5 for 4 groups, 
d 6 to 14 for all groups). The number of animals (1 or 2 /group) was based on the number of loggers available. The loggers were attached to the outer side of one hind leg (metatarsus; half of the loggers were attached to left legs, half to the right). Loggers were placed inside durable fabric pouches and wrapped using Vetrap, a self-adherent bandage (3M, St. Paul, MN). Vetrap was placed above and around the device. The loggers were set to record if cows were standing or lying every $1 \mathrm{~min}$. Halfway through the experiment, the loggers were switched to the opposite hind leg to minimize the chance of hair loss or irritation.

\section{Vocal Response}

The vocal response during and after the afternoon milking was recorded during $8 \mathrm{~d}$ (before dry off: $\mathrm{d} 1,3$, 5,7 ; during the same period after dry off: d 8, 9, 10, 14; same as time-budget data collection). The number of calls per group was continuously recorded during 5 -min intervals. The vocal responses of the $1 \times$ groups were measured while the $2 \times$ cows were milked ( $33 \pm 4 \mathrm{~min})$ and these observations began when the gate for the cows milked $2 \times$ was opened and these cows were moved toward the parlor. Vocal responses continued to be recorded in the $2 \mathrm{~h}$ following the end of the afternoon milking when all 4 treatment groups were present (117 $\pm 26 \mathrm{~min})$.

\section{Statistical Analysis}

Information from data loggers used to record lying behavior was lost on d 5 from 1 group and d 3 to 7 for a second group due to technical failure. Milk yield information was lost from 6 to 11 cows in various treatments because of failure of the computer in the parlor, for a total of 82 cow-days of lost information over $9 \mathrm{~d}$ of recording (minimum number of cows recorded/group = 2 ; thus, sample size was never reduced because of this lost information). To normalize residuals, a $\log _{10}$ transformation was used for milk yield, average duration of lying bouts, and number of lying bouts. An angular (arc sine) transformation was used for lying positions (expressed as percentage of lying time). All means and SEM were back-transformed for presentation in the results.

Groups served as the experimental unit for all analyses $(\mathrm{n}=16)$. When measurements were taken for multiple cows within a group, the group mean was used. All dependent variables except milk leakage, lying laterally, and udder health were analyzed with a repeatedmeasures ANOVA (PROC GLM; SAS Institute, 1999). Daily averages were calculated for each variable, and data were divided into 2 categories: before and after dry off. Separate models tested the overall effect of treatment (3 df in total: feeding level, $1 \mathrm{df}$, milking frequency, $1 \mathrm{df}$, and the interaction between these 2 treatments, $1 \mathrm{df}$ ) against an error term (12 df) for each category (before and after dry off). Within these models, the time by treatment interactions were tested with the Greenhouse-Geisser value, generated with an error term with, depending on how often the variable was measured, between 36 (e.g., 4 measurements before dry off) and $72 \mathrm{df}$ (e.g., 7 measurements before dry off). If the time $\times$ treatment interaction is not reported, then it was not significant $(P \geq 0.074)$.

For some data (milk leakage, lying laterally, udder health), the dependent variable was not suitable for ANOVA. In 2 cases (milk leakage and lying laterally), the proportion of cows (leaking milk, lying laterally at least once in a 24-h period) in each group was analyzed with the events/trials (e.g., number of cows with leaking milk per group/group size) function of PROC LOGISTIC in SAS. The model tested the overall effect of treatment ( $3 \mathrm{df}$ in total: feeding level, $1 \mathrm{df}$, milking frequency, $1 \mathrm{df}$, and the interaction between these 2 treatments, $1 \mathrm{df})$ against an error term (12 df). Udder health was summarized as the percentage of groups with at least 1 cow affected by CM and prevalence of new IMI by Strep. uberis and analyzed with a Fisher's exact test (PROC FREQ; SAS Institute, 1999). Udder health traits were only seen and considered on d 15, but for other variables, each day was analyzed separately.

\section{RESULTS}

\section{Milk Yield, Milk Leakage, and Udder Firmness}

Milk yield was similar among treatments at the start of the experiment $(9.3 \pm 1.0 \mathrm{~kg} / \mathrm{d} ; P \geq 0.488)$, but declined when cows were offered $8 \mathrm{~kg}$ of $\mathrm{DM} / \mathrm{d}$ or milked $1 \times\left(\right.$ Figure $\left.1 ; P_{\text {feed }}=0.016, P_{\text {milking }}=0.017\right)$. The decline in milk yield over the $7 \mathrm{~d}$ was particularly marked for both treatments $\left(P_{\text {treatmentxtime }}<0.001\right)$. On the last day of milking ( 7 of experiment), cows offered $8 \mathrm{~kg}$ of DM/d produced $34 \%$ less milk than cows offered $16 \mathrm{~kg}$ of $\mathrm{DM} / \mathrm{d}$, and cows milked $1 \times$ produced $20 \%$ less milk than those milked $2 \times$. Despite the striking differences in milk yield, the number of cows leaking milk, an average $2 \%$ of cows, was similar across all treatments before dry off $\left(P_{\text {feed }} \geq 0.968, P_{\text {milking }} \geq 0.943\right)$. On d 9 and 10 of the experiment (second and third day after dry off, respectively), cows offered $16 \mathrm{~kg}$ of DM/d were more than twice as likely to leak milk compared with cows offered $8 \mathrm{~kg}$ of DM/d (Figure 2; $P_{\text {feed }} \leq 0.020$ ). There were no differences in milk leakage associated with milking frequency or feed level on any other day after dry off $\left(P_{\text {feed }} \geq 0.400, P_{\text {milking }} \geq 0.214\right)$. The $8 \mathrm{~kg}$ of 


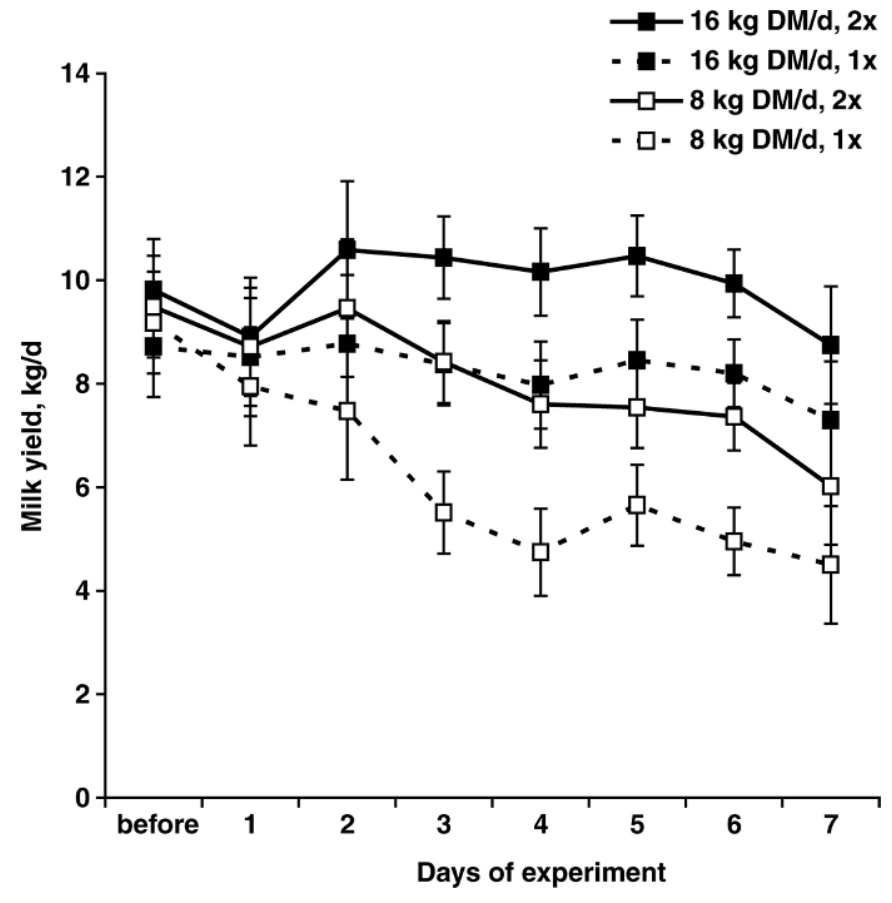

Figure 1. Milk yield $(\mathrm{kg} / \mathrm{d}, \pm \mathrm{SEM})$ of cows offered either 16 or 8 $\mathrm{kg}$ of $\mathrm{DM} / \mathrm{d}$ and milked either once $(1 \times)$ or twice $(2 \times)$ daily. Milking treatments were imposed on $d 1$ to 7 of the experiment; the "before" period is an average of the $3 \mathrm{~d}$ before the experiment began.

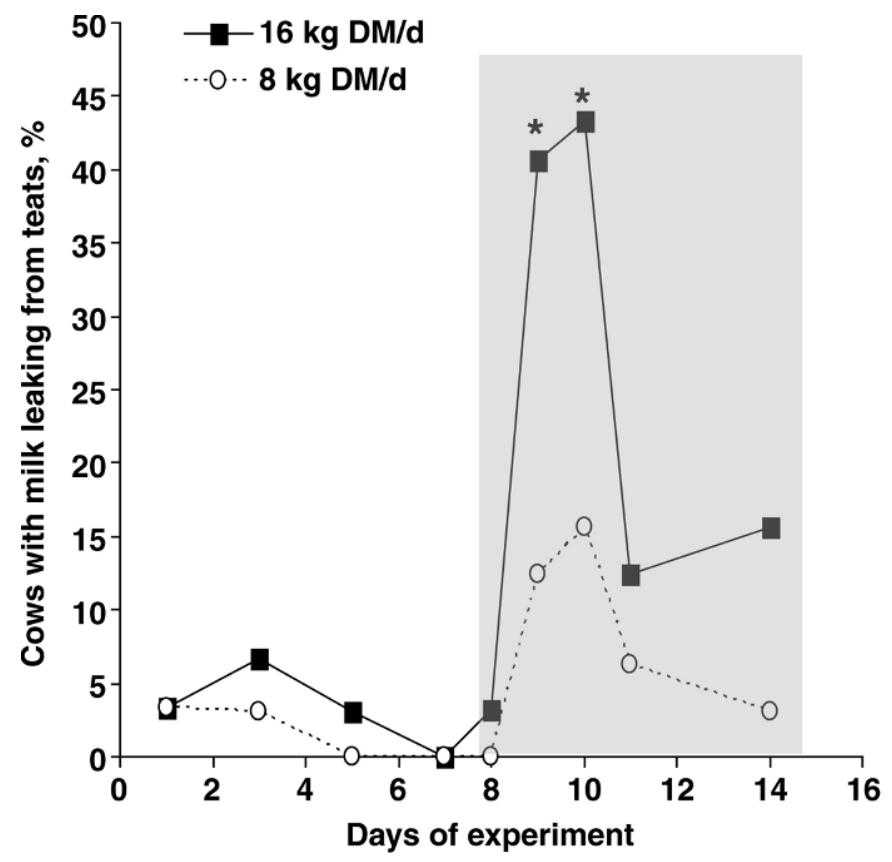

Figure 2. Percentage of cows with milk leaking from teats. Cows were offered 16 or $8 \mathrm{~kg}$ of $\mathrm{DM} / \mathrm{d}$ for the $7 \mathrm{~d}$ before (d 1 to 7 of experiment) and the $7 \mathrm{~d}$ after the end of lactation or dry off (d 8 to 14 of experiment, shaded). Asterisks indicate significant differences at $P<$ 0.05 .

Journal of Dairy Science Vol. 92 No. 7, 2009

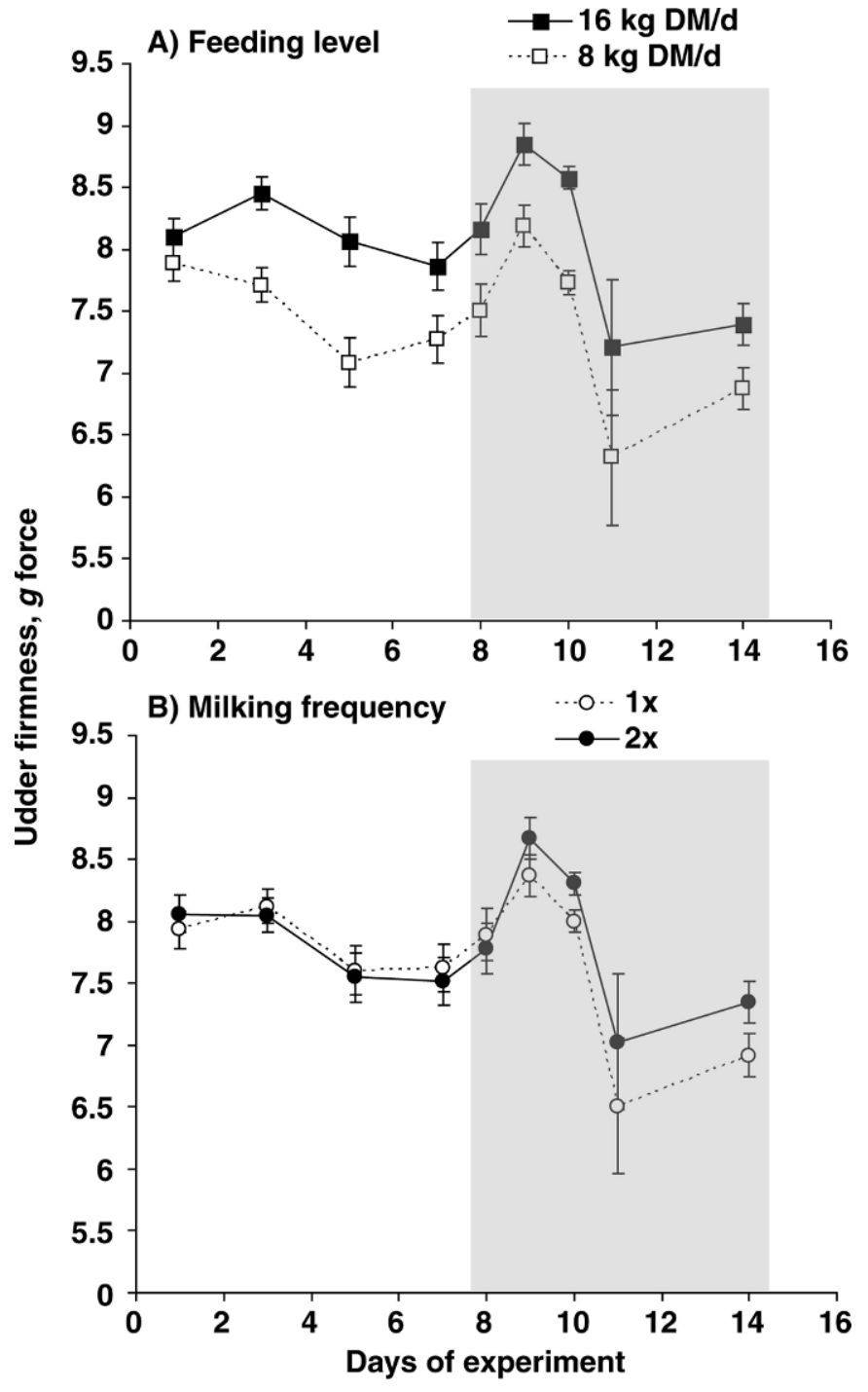

Figure 3. Mean udder firmness ( $g$ force, \pm SEM) of cows that had been offered 16 or $8 \mathrm{~kg}$ of DM/d (panel A) or milked once $(1 \times)$ or twice $(2 \times$, panel B) during the experiment. Milking ended and the dry-off period (shaded) began on d 8 of the experiment.

$\mathrm{DM} / \mathrm{d}$ feeding treatment reduced udder firmness before and after dry off (Figure 3; $P_{\text {feed }} \leq 0.012$ ), and the pattern of change differed in the feeding treatments before dry-off $\left(P_{\text {feedxtime }}=0.003\right)$. Cows milked $1 \times$ tended to have slightly softer udders after dry off (Figure 3; $\left.P_{\text {milking }}=0.098\right)$, but not before milking ended $\left(P_{\text {milking }}\right.$ $=0.900)$. There were no interactions between feeding level and milking frequency for any of these variables (yield, leakage, or firmness; $P_{\text {feed } \times \text { milking }} \geq 0.487$ ).

\section{IMI}

Four quarters across 3 cows received DCT at dry off and were excluded from further analysis. No new cases 
Table 2. Percentage of groups with at least one cow with clinical mastitis, IMI with no clinical signs, or total IMI caused by Streptococcus uberis on $\mathrm{d} 15$ of the experiment $(8 \mathrm{~d} \text { after dry off })^{1}$

\begin{tabular}{|c|c|c|c|c|c|c|}
\hline \multirow[b]{2}{*}{ Mastitis variable } & \multicolumn{2}{|c|}{ Feed offered } & \multirow[b]{2}{*}{$P_{\text {feed }}$} & \multicolumn{2}{|c|}{ Milking frequency } & \multirow[b]{2}{*}{$P_{\text {milking }}$} \\
\hline & $8 \mathrm{~kg}$ & $16 \mathrm{~kg}$ & & $1 \times$ & $2 \times$ & \\
\hline Clinical mastitis & 62.5 & 75.0 & 0.359 & 62.5 & 75.0 & 0.359 \\
\hline Strep. uberis IMI & 12.5 & 62.5 & 0.056 & 37.5 & 37.5 & 0.392 \\
\hline Strep. uberis infection & 62.5 & 87.5 & 0.246 & 75.0 & 75.0 & 0.431 \\
\hline
\end{tabular}

${ }^{1}$ Cows were offered either 16 or $8 \mathrm{~kg}$ of $\mathrm{DM} / \mathrm{d}$ and milked either once $(1 \times)$ or twice $(2 \times)$ daily in the week before dry off. $P$-values are reported separately for the feeding level and milking frequency treatments.

of CM were observed before dry off, but by d $15(7 \mathrm{~d}$ after dry off) CM was detected in 15 quarters across 13 cows in 11 groups, and Strep. uberis was isolated from all but one of these cases. A further 16 quarters across 13 cows developed new IMI that displayed no clinical signs (non-CM), and from these cases, Strep. uberis was isolated from 15 quarters and Staph. aureus from 1 quarter. In total, new IMI with Strep. uberis after dry off was detected in 30 quarters (0.12 of total quarters) across 25 cows ( 0.39 of total cows).

Cows offered $16 \mathrm{~kg}$ of $\mathrm{DM} / \mathrm{d}$ developed more cases of non-CM IMI by Strep. uberis compared with cows offered $8 \mathrm{~kg}$ of $\mathrm{DM} / \mathrm{d}\left(\mathrm{P}_{\text {feed }}=0.056\right)$, but no effect of milking frequency was observed (Table 2).

\section{Time Budgets and Lying Behavior}

Cows offered $16 \mathrm{~kg}$ of DM/d spent more time eating, by approximately $1 \mathrm{~h} / \mathrm{d}$, before $(8.3 \mathrm{vs} .7 .3 \pm 0.28 \mathrm{~h} / \mathrm{d})$ and after dry off (6.8 vs. $5.8 \pm 0.51 \mathrm{~h} / \mathrm{d} ; P_{\text {feed }} \leq 0.054$; Tables 3 and 4). Cows fed $16 \mathrm{~kg}$ of $\mathrm{DM} / \mathrm{d}$ spent approximately $1 \mathrm{~h} / \mathrm{d}$ less time lying down both before (7.3 vs. $8.8 \pm 0.24 \mathrm{~h} / \mathrm{d}$ ) and after dry off ( 8.5 vs. $9.4 \pm 0.35$ $\left.\mathrm{h} / \mathrm{d} ; P_{\text {feed }} \leq 0.021\right)$. Although feeding level influenced the total amount of time spent lying down, there were no differences in the number of lying bouts $(6 \pm 0.6$ bouts/d for both feeding levels; $P_{\text {feed }} \geq 0.103$ ) or duration of average lying bout $(16 \mathrm{~kg}$ of $\mathrm{DM} / \mathrm{d}: 71 \pm 8.2$ $\mathrm{min} /$ bout, $8 \mathrm{~kg}$ of DM/d: $82 \pm 8.2 \mathrm{~min} /$ bout; $P_{\text {feed }} \geq$ 0.249 ) before or after dry off. Lying bouts tended to be slightly longer if cows were only milked $1 \times$ before dry off ( 83 vs. $70 \pm 7.7 \mathrm{~min} /$ bout; $P_{\text {milking }}=0.057$ ). Milking frequency had no other effect on overall time budgets or lying behavior $\left(P_{\text {milking }} \geq 0.330\right)$.

Lying postures before and after dry off were influenced by feeding levels, but not by milking frequency $\left(P_{\text {milking }} \geq 0.286\right)$. Before dry off, cows offered $8 \mathrm{~kg}$ of $\mathrm{DM} / \mathrm{d}$ spent more time lying with their front, underside leg bent ( 85 vs. $77 \pm 2.3 \%$ lying time; Table 3 ). This was the case after dry off when several other positional changes occurred (Table 4). For example, cows offered $8 \mathrm{~kg}$ of $\mathrm{DM} / \mathrm{d}$ were more than twice as likely to lie with their hind leg touching their body compared with cows offered $16 \mathrm{~kg}$ of DM/d after dry off (Figure 4). They were more likely to lie with both front legs bent and with their weight shifted toward the center of their body (as indicated by contact between metacarpus and fetlock joint). Cows were more likely to lie laterally at

Table 3. Behavioral responses (mean \pm SEM) observed before dry off $(\mathrm{d} 1,3,5$, and 7 of the experiment) of cows milked once $(1 \times)$ or twice $(2 \times)$ daily and offered either a high $\left(16 \mathrm{~kg}\right.$ of DM/d) or low $\left(8 \mathrm{~kg}\right.$ of DM/d) level of feed ${ }^{1}$

\begin{tabular}{|c|c|c|c|c|c|c|c|}
\hline Behavior & \multicolumn{2}{|c|}{$16 \mathrm{~kg}$ of $\mathrm{DM} / \mathrm{d}$} & \multicolumn{2}{|c|}{$8 \mathrm{~kg}$ of $\mathrm{DM} / \mathrm{d}$} & SEM & $P_{\text {feed }}$ & $P_{\text {milking }}$ \\
\hline Eating $(\mathrm{h} / 24 \mathrm{~h})$ & 8.2 & 8.3 & 7.4 & 7.2 & 0.28 & 0.004 & 0.820 \\
\hline Lying $(\mathrm{h} / 24 \mathrm{~h})$ & 7.4 & 7.1 & 8.8 & 8.7 & 0.24 & $<0.001$ & 0.509 \\
\hline \multicolumn{8}{|l|}{ Positions while lying: } \\
\hline Underside front leg, bent ( $\%$ of lying time) & 77 & 76 & 84 & 85 & 2.3 & 0.005 & 0.987 \\
\hline Exposed front leg, touching (\% of lying time) & 4 & 7 & 8 & 7 & 2.8 & 0.442 & 0.756 \\
\hline Exposed hind leg, touching (\% of lying time) & 3 & 4 & 6 & 3 & 1.4 & 0.548 & 0.761 \\
\hline Neither front or hind leg touching (\% of lying time) & 49 & 42 & 36 & 45 & 7.8 & 0.534 & 0.913 \\
\hline $\begin{array}{l}\text { Combination of both front legs tucked and hind leg } \\
\text { touching the body (\% of lving time) }\end{array}$ & 3 & 4 & 5 & 3 & 1.3 & 0.543 & 0.745 \\
\hline
\end{tabular}

${ }^{1}$ Cows were milked $1 \times$ or $2 \times$ from the start of the experiment, $7 \mathrm{~d}$ before dry off, when all milking ended. $P$-values are reported separately for the feeding level and milking frequency treatments. 


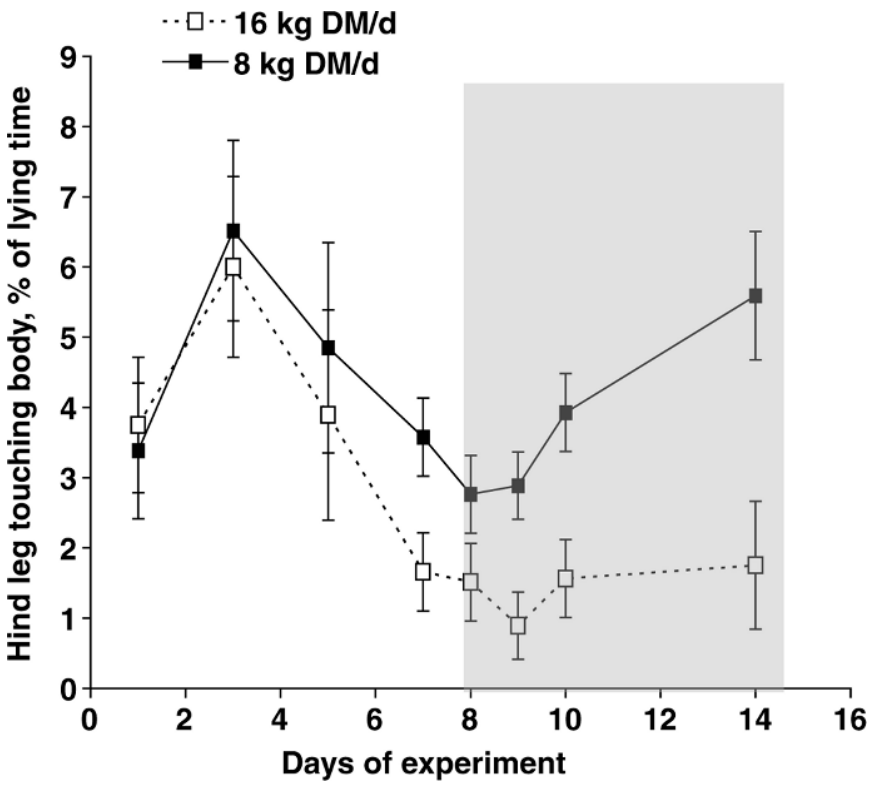

Figure 4. Percentage of lying time spent $( \pm \mathrm{SEM})$ with the hind leg touching the body when cows had been offered 16 or $8 \mathrm{~kg}$ of DM/d for the $7 \mathrm{~d}$ before ( $\mathrm{d} 1$ to 7 of experiment). Milking ended and the dry-off period (shaded) began on d 8 of the experiment.

least once in a 24 -h period if offered $16 \mathrm{~kg}$ of $\mathrm{DM} / \mathrm{d}$ on d 8 and 9 of the experiment (first and second day after dry off, $P_{\text {feed }} \leq 0.045$; Figure 5$)$. Neither milking frequency nor feed level influenced the proportion of cows lying laterally on any other days $\left(P_{\text {milking }} \geq 0.132\right.$, $\left.P_{\text {feed }} \geq 0.179\right)$.

\section{Vocal Response}

Before dry off, the vocal responses of cows milked $1 \times$ were monitored while the $2 \times$ cows were in the parlor.
During this time, groups of cows offered $8 \mathrm{~kg}$ of $\mathrm{DM} / \mathrm{d}$ vocalized at 3 times the rate of groups offered $16 \mathrm{~kg}$ of $\mathrm{DM} / \mathrm{d}\left(1.5 \pm 0.2\right.$ vs. $0.5 \pm 0.2$ calls $/ \mathrm{min}, P_{\text {feed }}=$ $0.018)$. After the $2 \times$ cows returned from milking and after dry off, cows offered $8 \mathrm{~kg}$ of DM/d continued to call at higher rates than cows offered $16 \mathrm{~kg}$ of DM/d (Figure $6, P_{\text {feed }} \leq 0.01$ ), especially on $\mathrm{d} 1,3$, and 5 $\left(P_{\text {feed } x \text { time }}=0.031\right)$. Neither milking frequency nor the interaction between milking frequency and feeding level influenced this response before or after dry off $\left(P_{\text {milking }}\right.$ and $P_{\text {feed } \times \text { milking }} \geq 0.468$ ).

\section{DISCUSSION}

This study is one of the first to evaluate the behavioral changes associated with 2 common management practices, feed restriction and reduced milking frequency, used to dry cows off. Milking cows $1 \times$ instead of $2 \times$ in the week before dry off reduced milk yield but had little effect on behavior before or after cessation of milking. Feed restriction reduced milk yield, udder firmness, and milk leakage, and tended to reduce the risk of IMI. Despite these benefits, cows offered only 8 $\mathrm{kg}$ of $\mathrm{DM} / \mathrm{d}$ spent less time eating and vocalized more often than cows offered $16 \mathrm{~kg}$ of DM/d.

At the start of the experiment, cows produced $9 \mathrm{~kg}$ of milk/d. Both feed restriction and milking $1 \times$ reduced milk yield over the $7 \mathrm{~d}$ that treatments were imposed (Figure 1), and by d 7, cows offered $8 \mathrm{~kg}$ of DM/d gave $34 \%$ less milk than those offered $16 \mathrm{~kg}$ of DM/d. These results agree with those from other studies of pasturefed, late-lactation cows fed to similar levels (Lacy-Hulbert et al., 1999), but are less than the $51 \%$ reduction associated with $48 \mathrm{~h}$ of feed deprivation (Agenäs et al., 2003). Reducing milking frequency resulted in a

Table 4. Behavioral responses (mean \pm SEM) observed after dry off $(\mathrm{d} 8,9,10$, and 14 of the experiment) of cows milked either once (1×) or twice $(2 \times)$ daily before dry off and offered either a high $(16 \mathrm{~kg}$ of DM/d) or low $(8 \mathrm{~kg}$ of DM/d) level of feed throughout the experiment $(\mathrm{d} 1$ to 14$)^{1}$

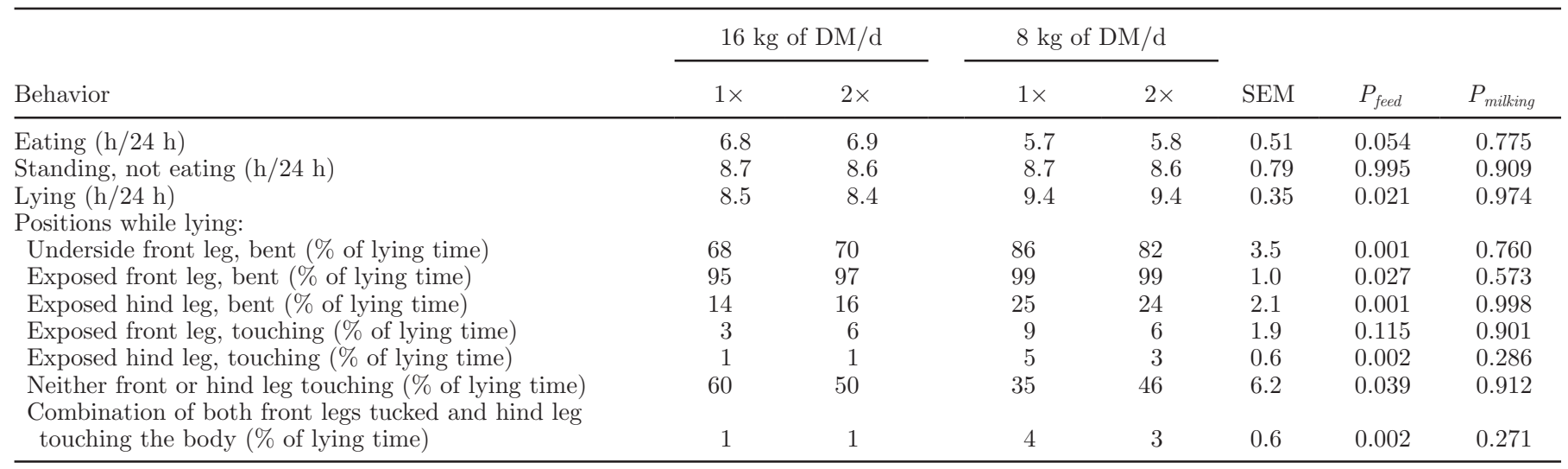

${ }^{1}$ Cows were milked $1 \times$ or $2 \times$ from the start of the experiment, $7 \mathrm{~d}$ before dry off, when all milking ended. Cows were not milked during the period presented in this table (after dry off). $P$-values are reported separately for the feeding level and milking frequency treatments. 


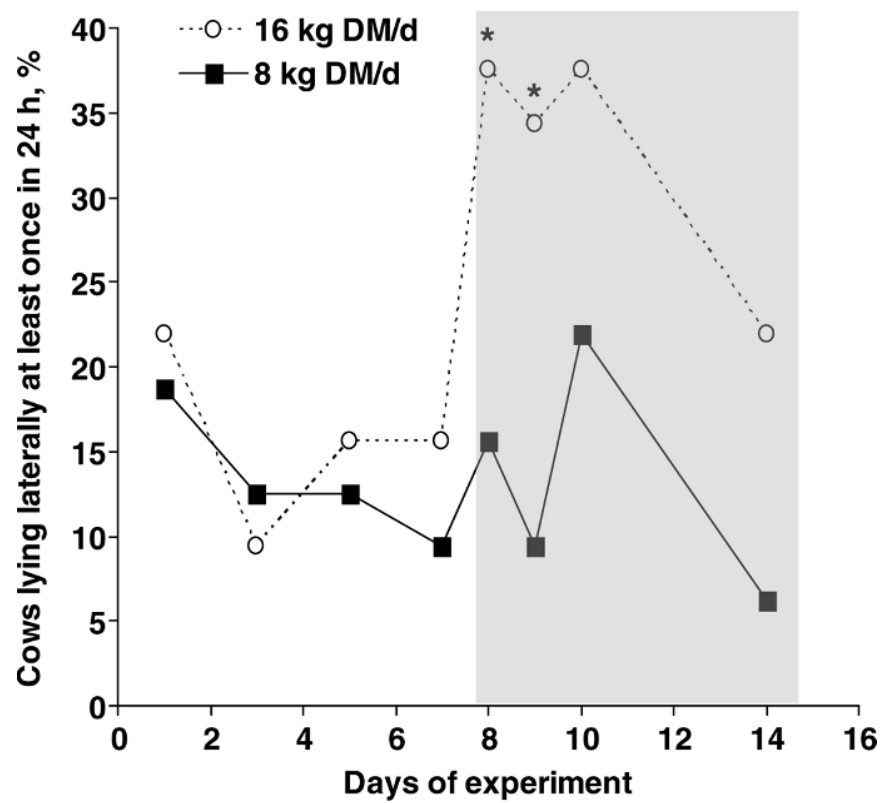

Figure 5. Percentage of cows that lie laterally (weight on side of body) at least once per 24-h period. Cows had been offered 16 or 8 $\mathrm{kg}$ of $\mathrm{DM} / \mathrm{d}$ for the $7 \mathrm{~d}$ before (d 1 to 7 of experiment) and the $7 \mathrm{~d}$ after the end of lactation or dry off (d 8 to 14 of experiment, shaded). Asterisks indicate significant differences at $P<0.05$.

smaller, but significant, $20 \%$ drop in milk yield for cows milked $1 \times$ compared with $2 \times$, a difference within the normal response to $1 \times$ milking (Davis et al., 1999).

Reducing milk yield before dry off was recommended to reduce the risk of new IMI, particularly if cows were producing $>12.5 \mathrm{~kg} / \mathrm{d}$ (Rajala-Schultz et al., 2005). Although milk yields were already $<12.5 \mathrm{~kg} / \mathrm{d}$ at the start of this experiment, a lower incidence of Strep. uberis mastitis tended to be observed among cows offered $8 \mathrm{~kg}$ of $\mathrm{DM} / \mathrm{d}$, supporting the recommendation that lowering milk yields before dry off reduces the risk of a new IMI after milking ends (Bushe and Oliver, 1987; Dingwell et al., 2004). In New Zealand, the environmental pathogen Strep. uberis is a major cause of new IMI in the dry period (Williamson et al., 1995; McDougall, 2003), but it was not possible to determine whether the scale of this reduction in new IMI would be sufficient to influence the bulk tank SCC in the subsequent season (McDougall, 2003) or the incidence of CM after calving.

Cows offered $16 \mathrm{~kg}$ of DM/d were more likely to leak milk. The increased risk of mastitis associated with greater levels of milk production at dry off was linked, at least in part, to teat closure: cows without teat closure were more likely infected (Dingwell et al., 2004). Although this experiment did not measure teat closure directly, previous work found that a lower level of feeding (similar to treatments imposed in this experiment) increased teat closure in the $14 \mathrm{~d}$ after cessation of milking (Summers et al., 2004).
In addition to concerns about open teats and exposure to pathogens, there was concern that udder distension caused discomfort. Feed restriction was associated with reduced udder firmness (Figure 3), which peaked $2 \mathrm{~d}$ after dry off. Previous work found that reducing milking frequency from $2 \times$ to $1 \times$ resulted in increased permeability of the tight junctions, and resulted in leakage of lactose into the blood in the $24 \mathrm{~h}$ after this change (Stelwagen et al., 1997). It seems likely that complete cessation of milking would result in udder distension. Indeed, cows milked more frequently tended to have firmer udders after dry off, although the magnitude of this difference was smaller (4\%) than the change associated with feeding level (9\%). At mid-lactation, cows undergoing the transition from $2 \times$ to $1 \times$ more likely leaked milk and had firmer udders (Tucker et al., 2007), but the level of milk production was greater than during the current experiment.

We predicted that discomfort associated with udder distension or firmness would correspond with changes in lying behavior. Cows fed less spent about $1 \mathrm{~h}$ more time lying down per day, both before and after dry off. It is unclear if this difference was due to less discomfort (because of softer udders) or to differences in time budgets as cows fed less also spent about $1 \mathrm{~h}$ less time eating. Previously, we reported that cows spending more time eating also spent less time lying down (Tucker et al., 2007) and suggested that a shift in time budgets was the simplest explanation for our results. In

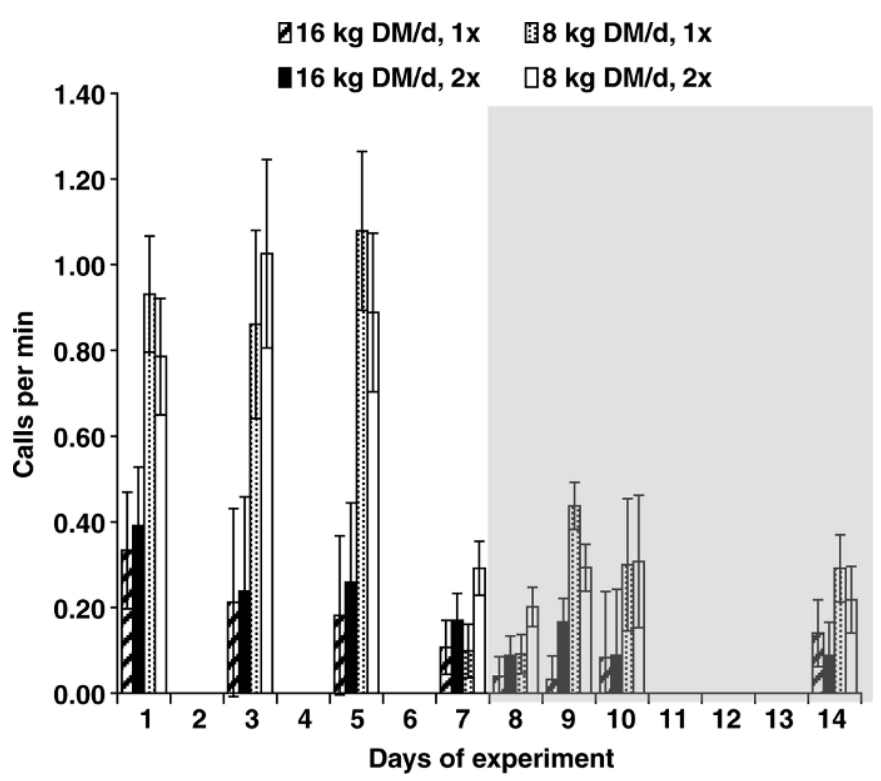

Figure 6. Vocal responses (calls/min; \pm SEM) of cows offered 16 or $8 \mathrm{~kg}$ of $\mathrm{DM} / \mathrm{d}$ and milked either once $(1 \times)$ or twice $(2 \times)$ daily during $2 \mathrm{~h}$ after the p.m. milking. Milking treatments were imposed on $\mathrm{d} 1$ to 7 of the experiment. The shaded area represents the end of lactation or dry off. 
contrast, previous studies reported reduced lying times associated with less frequent milking $(2 \times$ vs. $3 \times$ daily or omitted milking; Stefanowska et al., 2000; Österman and Redbo, 2001). Others interpreted the decrease in lying time as a sign of discomfort associated with udder distension; however, we were unable to replicate these results, even in the days immediately following dry off, when milk accumulation and discomfort were greatest. In addition to lying time, we predicted that cows experiencing udder discomfort would have fewer and shorter lying bouts to reduce pressure on the mammary gland (Österman and Redbo, 2001). Neither prediction was supported as there was no difference in behavior associated with feed level, and cows milked $1 \times$ had slightly longer lying bouts (opposite direction to prediction) than cows milked $2 \times$ before dry off.

We predicted that cows milked only $1 \times$ or those offered $16 \mathrm{~kg}$ of DM/d would more likely lie in positions that reduced pressure on the udder; namely with the hind leg away from the body, weight on the side of the body by using the exposed front leg as a fulcrum, or by lying with the weight on the side of the body (laterally). Both before and after dry off, cows fed less spent more time lying with the underside front leg bent. Because this difference occurred both before and after dry off, this change in lying position was not related to udder discomfort. One alternative explanation for this change in posture was that animals fed $8 \mathrm{~kg}$ of $\mathrm{DM} / \mathrm{d}$ likely had reduced rumen content compared with their $16 \mathrm{~kg}$ of DM/d counterparts, perhaps making it more comfortable to lie with both front legs bent.

In contrast, other lying positions, such as lying with the hind leg touching the body or udder and lying with weight on the side of the body (lying laterally), did not differ before dry off. Nevertheless, after dry off cows fed more were more likely to lie laterally and spent less time lying with the hind leg tucked up against their body (Figures 4 and 5 ). It is possible that cows lie in this manner because of discomfort associated with udder distension, but we have reservations about this interpretation. We were unable to replicate the current results when cows undergo the transition from $2 \times$ to $1 \times$ milking at mid-lactation. At that time, there were no changes in lying posture, despite increased udder firmness and leakage (Tucker et al., 2007).

Time spent eating was approximately $1 \mathrm{~h}$ less when cows were offered 8 compared with $16 \mathrm{~kg}$ of $\mathrm{DM} / \mathrm{d}$. The direction of this result is intuitive, as cows fed less would be expected to spend less time eating. The magnitude of the difference between eating time, 19 and $12 \%$, before and after dry off, respectively, was not proportional to the likely difference in intake $(50 \%)$ suggesting that feed intake does not necessarily correspond to eating time because of differences in bite size and rate (Nielsen, 1999). In addition, the relatively small difference in eating time compared with feed offered might indicate that cows increased search time to better utilize limited feed.

As with eating time, feeding level influenced the vocal response both before and after dry off (Figure 6). Cows offered $8 \mathrm{~kg}$ of $\mathrm{DM} / \mathrm{d}$ vocalized more than cows offered unrestricted access to feed, regardless of milking frequency. This pattern of increased vocalization was particularly marked in the first $5 \mathrm{~d}$ of the experiment; overall calling rate declined after this time. Anecdotally, we observed that cows were calling in response to specific stimuli (e.g., farm worker driving past the paddock), especially immediately after treatments were imposed. Vocalizations provide information about animal emotions (Watts and Stookey, 2000), and about the signaler's physiological condition or need (Godfray, 1995). Other authors documented cows calling in anticipation of food, but do not describe details of feeding levels (Yeon et al., 2006), making it difficult to compare results. Cows offered only $8 \mathrm{~kg}$ of DM/d had increased vocal response and it seems that this increase in calling rate may be an indicator of hunger. An alternative, and perhaps more humane, way to both reduce milk production and minimize the potential discomfort associated with udder distension without causing hunger would be to offer lower quality feeds at unrestricted levels. Feeding low-quality forage reduced both milk production (Odensten et al., 2005) and vocal response (Valizaheh et al., 2008), thus providing health benefits of lower milk yield while reducing hunger.

\section{CONCLUSIONS}

Based on the measures of milk leakage, udder firmness, and IMI, this experiment indicated that it was beneficial to reduce feed allowance of dairy cattle during the dry-off period. The vocal response to the $8 \mathrm{~kg}$ of $\mathrm{DM} / \mathrm{d}$ treatment suggests that cattle experienced hunger when feed was restricted. Thus, further information about alternative dry-off procedures, such as offering unrestricted access to low-quality diets, is needed to mitigate hunger but maintain the health benefits and comfort associated with reduced milk yield before dry off.

\section{ACKNOWLEDGMENTS}

We gratefully acknowledge the technical assistance from AgResearch and DairyNZ staff: Tania Blackmore, Elizabeth Blythe, Katie Carnie, Daniel Cullen, Antonia Davies, Debbie Davison, Suzanne Dowling, Nicola Haworth, Frankie Huddart, Paul Kendall, Estelle Liedemann, Phil Martin, Dai Morgan, Sally Robinson, 
Andrea Rogers, Karin Schütz, and Haley Shepherd. The project would not have been possible without the management skills of Jennie Lynn Burke and Kate Brown. We are grateful to Christoph Winckler at BOKU (Vienna, Austria) and Dan Weary (University of British Columbia, Vancouver, Canada) for the use of their Gemini data loggers. This work would not have been possible without funding from Ministry of Agriculture and Forestry, New Zealand.

\section{REFERENCES}

Agenäs, S., K. Dahlborn, and K. Holtenius. 2003. Changes in metabolism and milk production during and after feed deprivation in primiparous cows selected for different milk fat content. Livest. Prod. Sci. 83:153-164.

Bushe, T., and S. P. Oliver. 1987. Natural protective factors in bovine mammary secretions following different methods of milk cessation. J. Dairy Sci. 70:696-704.

Davis, S. R., V. C. Farr, and K. Stelwagen. 1998. Once-daily milking of dairy cows: An appraisal. Proc. N.Z. Soc. Anim. Prod. 58:3640.

Davis, S. R., V. C. Farr, and K. Stelwagen. 1999. Regulation of yield loss and milk composition during once-daily milking: A review. Livest. Prod. Sci. 59:77-94.

Dingwell, R. T., K. E. Leslie, Y. Schukken, J. M. Sargeant, L. L. Timms, T. E. Duffield, G. P. Keefe, D. E. Kelton, K. D. Lissemore, and J. Conklin. 2004. Association of cow and quarter-level factors at drying-off with new intramammary infections during the dry period. Prev. Vet. Med. 63:75-89.

Farr, V. C., C. G. Prosser, and S. R. Davis. 2000. Effects of mammary engorgement and feed withdrawal on microvascular function in lactating goat mammary glands. Am. J. Physiol. Heart Circ. Physiol. 279:813-818.

Godfray, H. C. J. 1995. Signaling of need between parents and youngParent-offspring conflict and sibling rivalry. Am. Nat. 146:1-24.

Lacy-Hulbert, S. J., M. W. Woolford, G. D. Nicholas, C. G. Prosser, and K. Stelwagen. 1999. Effect of milking frequency and pasture intake on milk yield and composition of late lactation cows. J. Dairy Sci. 82:1232-1239.

McDougall, S. 2003. Management factors associated with the incidence of clinical mastitis over the non-lactation period and bulk tank somatic cell count during the subsequent lactation. N. Z. Vet. J. 51:63-72.

Nielsen, B. L. 1999. On the interpretation of feeding behaviour measures and the use of feeding rate as an indicator of social constraint. Appl. Anim. Behav. Sci. 63:79-91.

NMC. 1999. Laboratory Handbook of Bovine Mastitis. National Mastitis Council Madison, WI.
Odensten, M. O., B. Berglund, K. P. Waller, and K. Holtenius. 2007a. Metabolism and udder health at dry-off in cows of different breeds and production levels. J. Dairy Sci. 90:1417-1428.

Odensten, M. O., Y. Chilliard, and K. Holtenius. 2005. Effects of two different feeding strategies during dry-off on metabolism in highyielding dairy cows. J. Dairy Sci. 88:2072-2082.

Odensten, M. O., K. Holtenius, and K. P. Waller. 2007b. Effects of two different feeding strategies during dry-off on certain health aspects of dairy cows. J. Dairy Sci. 90:898-907.

Österman, S., and I. Redbo. 2001. Effects of milking frequency on lying down and getting up behaviour in dairy cows. Appl. Anim. Behav. Sci. 70:167-176.

Rajala-Schultz, P. J., J. S. Hogan, and K. L. Smith. 2005. Short communication: Association between milk yield at dry-off and probability of intramammary infections at calving. J. Dairy Sci. 88:577-579

Roche, J. R., P. G. Dillon, C. R. Stockdale, L. H. Baumgard, and M. J. VanBaale. 2004. Relationships among international body condition scoring systems. J. Dairy Sci. 87:3076-3079.

SAS Institute. 1999. User's Guide: Statistics. Version 9.1 edition. SAS Inst., Inc., Cary, NC, USA.

Shennan, D. B., and M. Peaker. 2000. Transport of milk constituents by the mammary gland. Physiol. Rev. 80:925-951.

Stefanowska, J., M. Plavsic, A. H. Ipema, and M. M. W. B. Hendriks. 2000. The effect of omitted milking on the behaviour of cows in the context of cluster attachment failure during automatic milking. Appl. Anim. Behav. Sci. 67:277-291.

Stelwagen, K., V. C. Farr, H. A. McFadden, C. G. Prosser, and S. R. Davis. 1997. Time course of milk accumulation-induced opening of mammary tight junctions, and blood clearance of milk components. Am. J. Physiol. 273:R379-R386.

Summers, E. L., S. J. Lacy-Hulbert, J. H. Williamson, and B. P. Sugar. 2004. Influence of feeding level after drying off on incidence of mastitis and keratin plug formation in dairy cows. Proc. N.Z. Soc. Anim. Prod. 64:48-52.

Tucker, C. B., D. E. Dalley, J. L. K. Burke, and D. A. Clark. 2007. Milking cows once daily influences behavior and udder firmness at peak and mid lactation. J. Dairy Sci. 90:1692-1703.

Valizaheh, R., D. M. Veira, and M. A. G. von Keyserlingk. 2008. Behavioural responses by dairy cows provided two hays of contrasting quality at dry-off. Appl. Anim. Behav. Sci. 109:190200.

Watts, J. M., and J. M. Stookey. 2000. Vocal behaviour in cattle: The animal's commentary on its biological processes and welfare. Appl. Anim. Behav. Sci. 67:15-33.

Williamson, J. H., M. W. Woolford, and A. M. Day. 1995. The prophylactic effect of a dry-cow antibiotic against Streptococcus uberis. N. Z. Vet. J. 43:228-234.

Yeon, S. C., J. H. Jeon, K. A. Houpt, H. H. Chang, H. C. Lee, and H. J. Lee. 2006. Acoustic features of vocalizations of Korean native cows (Bos taurus coreanea) in two different conditions. Appl. Anim. Behav. Sci. 101:1-9. 